\title{
Maternal Schooling, Public Health Programmes and Child Morbidity in Nigeria
}

\author{
Odubunmi Ayoola Sunkanmi ${ }^{1} \&$ Omobitan Olufunsho Abayomi ${ }^{1}$ \\ ${ }^{1}$ Department of Economics, Lagos State University, Ojo, Lagos, Nigeria \\ Correspondence: Odubunmi Ayoola Sunkanmi, Department of Economics, Lagos State University, Ojo, Lagos, \\ Nigeria. E-mail: s.odubunmi2007@yahoo.com
}

Received: October 17, 2013 Accepted: March 8, 2014 Online Published: April 29, 2014

doi:10.5539/ass.v10n10p68 URL: http://dx.doi.org/10.5539/ass.v10n10p68

\begin{abstract}
The role of investment in human resources and subsequent multiplier on the economic growth of any nation has been adequately addressed in the literature. Education, a major investment in human resources helps in improving the productivity of labour in the labour market and also in influencing children mental alertness and health outcomes. Maternal education and public health programmes have been found to impact positively on child morbidity in developed countries thereby contributing to the growth of any economy, which will bring about sustainable development and inclusive growth. This work therefore examines the influence of maternal education and public health programmes on child health (morbidity) in Nigeria using the Harmonised Nigeria Living Standard Survey (2009). Descriptive Statistics and two stage least square estimation procedure were used to analyse the data. The results revealed a negative relationship between child immunisation and child health (morbidity) in Nigeria. Equally, the study found out that improving girl child education will go a long way in improving child morbidity. Based on our findings, the study recommends adequate publicity for public health programmes. Also, household income enhancing interventions should be put in place, doing this will go a long way in improving child health and survival, which in the long-run will improve per-capita income and consumption.
\end{abstract}

Keywords: maternal, public health, morbidity, child survival

\section{Introduction and the Background}

Developed countries of the world have recorded improvement in their health indices and outcomes due to government investment in health and education, the reverse is the case for most African countries including Nigeria, despite her huge resources and annual budgetary provisions for health and education. According to NDHS (2009) statistics, population having access to potable water is less than half, it is even worse in the rural areas. There is equally a disparity in terms of access to satisfactory sanitation conditions between the rural and urban areas (32\% and $41 \%$ respectively). Adult literacy rate is $56 \%$ and percentage of male is $67 \%$, which is much higher than females. Vivid examinations of these statistics have shown that child survival and maternal health are adversely affected. Studies have shown that child health in Nigeria is affected by; nutritional deficiencies and diseases such as malaria, diarrheal, acute respiratory infection and a host of others. In view of this, it is imperative for government to put in place sound policies by putting in place programmes that will arrest the unwholesome situation so that Nigerian children can survive and live quality life. This study therefore attempts to examine the effect of mother's education and the level of responses of mothers to public health intervention programmes on child's health and survival. This paper has been divided into five sections as follows: section two reviews the relevant literatures, child morbidity and public health programmes in Nigeria is the major pre-occupation of section three. Section four is the theoretical framework, methodology, results presentation and discussion, while section five concludes and gives policy implications.

\section{Literature Review}

The role of investment in human resources and the subsequent multiplier on the economic growth of any nation has been adequately addressed in the literature. Education which is the major investments in human resources helps in improving the productivity of labour in the labour market and even in influencing children mental alertness and health outcomes. Thus, Strauss and Thomas (1998) are of the opinion that human capital in form of schooling is associated with enhanced labour output. Investment in health is also an investment in human 
resources. Health according to Rubalcava and Tervei (2004) is a good that each household produces and allocated between market and non-market activities. A further probe into the literature have revealed that parental socio-economic status is highly correlated with child's morbidity through child rearing technology and family resource allocation. The effect is also felt in child performance in school, job prospects and life expectancy. (Wachs, 1995; Strauss \& Thomas, 1998; Beaton et al., 1993; Bleichralt \& Born, 1994). According to Bloom and Canning (2003), there are four major ways in which healthier individuals affect the economy: be more productivity at work, which enables them to secure high income earning jobs; less job turnover rate; get more education, which will transform into improved productivity and be able to safe more for the future, which translates into more funds for the economy that could be invested in the long run. Morbidity, according to Case et al. (2005) persists from infant into adulthood, which later contributes to the health income gradient in the latter part of life. Government across the world has put in place various measures to tackle this problem by investing in health, most especially, maternal and child health. Programmes like targeted exemption schemes, or free health services for pregnant women, nursing mothers, under five children and infants have been put in place. (Cesar et al., 1992). According to Gwatkin (2003), it is a herculean task for most developing countries to achieve a minimal level of adequacy in health care service because of the paradox in their health care service. According to him, while the health care needs of developing nations are increasing government expenditure on health in sub-Saharan Africa is grossly inadequate, inequitable and unsustainable. The world Bank (2004), accessing the health care system of some selected developing countries supported the position of Gwarking (2003) and opines that inadequate health expenditure in developing countries inhibits access to adequate health care especially among women and children. Cesar et al. (1992)'s studies reveals that maternal education impacts on child morbidity and mortality. However, evidence from developing countries shows high incidence of child morbidity in spite of increasing maternal education and health intervention programmes. Cadwell (1979) reveals that mother's education is very crucial to child health outcomes than father's education and socio-economic status; however, some studies such as (Desai \& Alva, 1998; Basu, 1994; Hobcraft, 1993) have challenged these findings. According to Kurz et al. (1994), the length of schooling of girls determines their level of self-esteem and confidence. Thus, the longer the schooling years of a girl, the higher the self-esteem and confidence. Adeoti et al. (2009)'s study show that accessibility of women to education and employment enhances their overall chances of employment, which gives them adequate access to health and in the long run improves their life chances. Women that lack education on the other hand are prone to a lot of health risks for themselves and their children. Policy project/Nigeria (2002) reports women education as a major determinant of child's health. According to the report "the higher a woman's level of education, the more likely it is that she will marry later, play a greater role in decision making and exercise her reproductive rights. Her children will tend to be better nourished and enjoy better health". From the fore-going, it is imperative that girl child education is very crucial to child health and survival.

\section{Child Morbidity and Public Programmes in Nigeria}

According to NPC (2006), Nigeria population is well over 140 million and this makes it the $10^{\text {th }}$ most populous nation in the world and first in Sub-Sahara Africa. In terms of the population structure, $63.7 \%$ is rural, while about $45 \%$ and $20 \%$ are within 15 and under five age brackets respectively (NBS, 2008). The Gross Domestic Product (GDP) per capital is $\$ 2,800$ in 2012 (compared to $\$ 512,612$ in the U.S), this is lower among people in the rural areas thereby affecting the quality of life negatively (World Bank, 2012; UNDP, 2012). The GDP growth is $7.1 \%$ by 2012 estimate; inflation (CPI) by 2012 estimate is $11.9 \%$, while population below poverty level is $45 \%$. The Human Development Index (HDI) ranks Nigeria 156 with 0.459 values out of 187 countries in the world, this shows that Nigeria has not performed well in terms of human development. Education index in U.S is 0.939 compared to Nigeria's 0.457 . The value places Nigeria at the bottom, meaning a low level of human development. The value of the education index is 0.457 , compared to the average in the U.S of 0.939 . (World Bank, 2012; UNDP, 2012). The World Bank Statistics (2012) further shows that less than one-half of the population has access to safe water ( $40 \%$ in the rural areas) and only 41 percent have access to adequate sanitation (33\% in rural areas). The adult literacy rate is 56 percent, males (67\%) and females (47\%). All these facts adversely affect the survival of children and the reproductive health $(\mathrm{RH})$ status of women in general. These statistics show that Nigerians especially people living in the rural areas have limited access to adequate nutrition, quality health care, and other basic social services especially among women and children. In terms of improvements in child survival, Nigeria is ranked among the least successful countries in Africa in the past four decades. Child survival in Nigeria is threatened by nutritional deficiencies and illness, particularly malaria, diarrheal diseases, acute respiratory infection (ARI) and vaccine preventable diseases (VPD) which account for the majority of morbidity and mortality in childhood. The table below shows the rate of infant mortality and morbidity with different nature of their causal diseases in 2010. 
Table 1. Children's morbidity/mortality rate by nature of disease in Nigeria 2010

\begin{tabular}{|c|c|c|c|c|c|c|}
\hline Disease cause & $\begin{array}{l}\text { Percentage } \\
\text { Mortality } \\
\text { five }\end{array}$ & $\begin{array}{r}\text { of } \\
\text { Under }\end{array}$ & Infant & $\begin{array}{l}\text { Percentage } \\
\text { Morbidity } \\
\text { five }\end{array}$ & $\begin{array}{r}\text { of } \\
\text { Under }\end{array}$ & Infant \\
\hline Typhoid & 3 & & NA & $\mathrm{NA}$ & & NA \\
\hline VPD & 22 & & 22 & 15 & & 17 \\
\hline ARI & 16 & & 22 & 15 & & 15 \\
\hline Diarrheal & 19 & & 24 & 24 & & 27 \\
\hline Malaria & 30 & & 28 & 41 & & 38 \\
\hline Malnutrition & 2 & & $\mathrm{NA}$ & $\mathrm{NA}$ & & NA \\
\hline Others & 8 & & 4 & 5 & & 3 \\
\hline
\end{tabular}

Source: Nigeria Demographic Health Survey, 2010

In addition to table one above, the United Nations Population Fund's report of 2010 shows that maternal mortality rate has deteriorated to 840 per 100,000 in 2010 compared to 608.3 and 473.4 in 2008 and 1990 respectively. It was equally estimated that 37,000 maternal deaths occurs in Nigeria annually compared to 340 and 610 in South Africa and Zimbabwe respectively, making Nigeria the second highest in the world in terms of maternal deaths. (FMOH, 2010). A Nigerian child is reported to likely die before attaining age five compared to a child in developed countries (UNICEF, 2012). However, in a bid to increase child survival, the government of Nigeria has put in place a lot of programmes these include: establishment of child-mother hospitals, free medication for pregnant mothers, Roll-Back-Malaria, National programme on Immunisation and a host of others. Despite all these programmes, child survival indices still remain the worst in sub-Saharan Africa, due to inadequate planning and funding, lack of intersectional linkages and poor management of limited funds available. Table 2 below shows the current situation of child survival indicators in Nigeria.

Table 2. Child survival indicators in Nigeria

\begin{tabular}{ll}
\hline Total population (millions) & 120 \\
Crude birth rate (CBR) (Per 1,000) & 41 \\
Total fertility rate (TFR) births per woman & 5.2 \\
Unmet need for family planning (FP)\% & 18 \\
Infant mortality rate (IMR) (Per 1,000) & 71 \\
Under 5 mortality rate (U5MR) (per 1,000) & 140 \\
Child mortality rate (CMR) (per 1,000) & 67 \\
Neonatal Mortality rate (per 1,000) & 35 \\
Low birth weight (\%) & 16 \\
Percent of infants <6 months exclusively breastfed & 1 \\
Percent of children stunted (height-for-age, below 2SD) & 46 \\
Percent of children wasted (weight-for-height, below 2SD) & 12 \\
Percent of children underweight (weight-for-age, below 2SD) & 27 \\
Percent of children 12-23 months fully immunized & 17 \\
Maternal mortality ratio (per 100,000 live births) & 800 \\
Number of orphans (double, maternal, paternal and causes in 2000) & $2,591,744$ \\
\hline
\end{tabular}

Source: Author's compilation from different sources, 2006; NPC, 2009; HNLSS \& UNICEF 2009. 


\section{Theoretical Framework, Results Presentation and Discussion}

Grossman seminal work on health care demand (1972) has provided a framework where household production model can be used to investigate the correlation between child morbidity and some other health variables. To estimate the correlation between mother's education and child health or morbidity, Glewwe (1999) provides a framework that shows that child's health depends on health and nutritional inputs and the environment of the child.

Following Glewwe (1999), the utility function is expressed in the form;

$$
\mathrm{U}=\mathrm{U}\left(\mathrm{C}_{\mathrm{i}}, \mathrm{H}_{\mathrm{i}}, \mathrm{T}, \mathrm{E}_{\mathrm{i}}, \varepsilon_{\mathrm{i}}\right)
$$

Where;

$\mathrm{C}=$ Non health consumption that yields utility but does not have any effect on child health status.

$\mathrm{H}=$ Health of the child

$\mathrm{T}=$ Consumption of health-related products that yields utility but also directly affect child health status.

$\mathrm{E}=$ Environmental conditions surrounding the child and $\varepsilon$ is the initial child's health endowment. It needs be pointed out that $\mathrm{E}$ and $\varepsilon$ are exogenous variables, while health and nutritional inputs are endogenous determined by the household. Studies have shown that health status of the child is determined by several factors such as: parental education. Thus;

$$
\mathrm{H}=\Phi\left(\mathrm{MS}, \mathrm{HA}, \mathrm{E}, \mathrm{T}, \varepsilon_{\mathrm{i}}\right)
$$

Where:

MS = Mother's schooling

$\mathrm{HA}=$ Initial assets of child's household

$\mathrm{E}=$ as previously defined

$\varepsilon=$ as previously defined

$\mathrm{T}=$ as previously defined

The household's budget constraint is then expressed as:

$$
\mathrm{y}=\mathrm{P}_{\mathrm{c}}+\mathrm{T}_{\mathrm{p}}+\mathrm{Z}_{\mathrm{p}}
$$

Where

$\mathrm{y}=$ exogenous income

$\mathrm{Pc}, \mathrm{P}_{\mathrm{T}}$ and Pz are prices of; non-health good, health related good $(\mathrm{T})$ and health investment good (z) respectively. In equations (1) and (2) health as an investment good such as immunization is purchased only for the purpose of improving child health status so that it enters the household's utility function through H (Adeoti et al., 2007). This approach was faulted in the sense that regressing outcomes such as health on inputs will bring about biased estimates. Estimation of reduced form demand relations where health outcomes will be regressed on (exogenous) determinant of health inputs was suggested.

\subsection{Empirical Model of the Study}

In this study, child morbidity is defined as the rate and duration of sickness of children in a household. The factors affecting child morbidity in Nigeria include: childhood malnutrition, poor immunization status, maternal schooling/level of education, poor living conditions/environmental factors (housing, water and sanitation) among others. The data employed for this study HNLSS contains the rate and duration of illness of children in a household which is used to represent the child morbidity rate. The ratio of sick children to those children that were not sick gives the morbidity rate for the household. The probability is taken to be between zero and one. A household with no morbidity is assigned the probability of zero, otherwise one. Two stage least square estimation procedure was also used by this study to avoid biased and inconsistency of ordinary least square procedures. The dependent variable for this study is child morbidity rate. We assume factors such as child immunization status $\left(\mathrm{X}_{1}\right),(1$ if the child is immunized, 0 if otherwise). Child immunization status was then regressed against mother schooling status, ( 1 if fully or partially educated, if otherwise 0 ) environmental factors (access to housing and water) (1 if there's access, 0 if otherwise).

The household demographic characteristics adopted in this study include:

$\mathrm{X}_{2}=$ Mother's age in years 
$\mathrm{X}_{3}=$ Household area of residence ( 1 if resides in urban, 0 if resides in rural)

$\mathrm{X}_{4}=\mathrm{Log}$ of per capital expenditure on health

The structural equation is:

$$
\mathrm{CMD}=\Phi_{\mathrm{CMD}} \mathrm{X}_{\mathrm{i}}+\Psi \mathrm{I}+\varepsilon_{\mathrm{i}}
$$

$\Phi, \Psi, \varepsilon=$ Vectors of parameters we want to estimate and disturbance term

$\mathrm{CMB}=$ Child morbidity rate

$\mathrm{I}=$ Child immunization status

$\mathrm{Xi}=$ Vector of exogenous variables.

The reduced form of our endogenous variable (I) is then expressed in a reduced form equation:

$$
\mathrm{I}=\varnothing_{\mathrm{i}} \mathrm{X}+\sum \varepsilon_{\mathrm{i}}
$$

$\mathrm{X}=$ Exogenous variables consisting of $\mathrm{X}_{\mathrm{i}}$ and instrumental variables vector.

We define our instrumental variables as:

$\mathrm{X}_{11}=$ Educational $/$ schooling of mother

$\mathrm{X}_{21}=$ Types of housing

$\mathrm{X}_{31}=$ Access to drinking water (Accessibility is defined in terms of distance to safe drinking water in $\mathrm{km}$ ).

\subsection{Limitation of Data}

We observed a lot of limitations from the data used by this study. First, the HNLSS fails some major determinants of household's episode of illness. Besides, income was treated as exogenous which does not allow for capturing income loss as a result of illness. The data also fails to consider the quality of service being rendered by facility or health care provider. Finally, only in-patients were captured by the survey.

\section{Empirical Results and Interpretation}

Table 3. Descriptive statistics of sampled households

\begin{tabular}{lllllll}
\hline Characteristics & All & & Rural & & Urban \\
& Mean & Std. Dev & Mean & Std. Dev. & Mean & Dev \\
\hline Age of mother (years) & 34.52 & 12.02 & 33.95 & 12.04 & 36.63 & 12.12. \\
Schooling level of mothers (years) & 5.63 & 1.53 & 5.41 & 1.65 & 6.24 & 1.34 \\
Child Immunisation level & 0.44 & 0.89 & 0.33 & 0.88 & 0.45 & 0.89 \\
Log per capital expenditure on wealth & 20.24 & 2.53 & 20.43 & 2.63 & 20.42 & 2.47 \\
Access to drinking water (Distance to drinking water) & 2.42 & 1.21 & 2.83 & 1.31 & 2.08 & 1.06 \\
\hline
\end{tabular}

The descriptive statistics above shows that the average age of mothers is 34.52 years, meaning that they are within the productive working class age. However, there is a little disparity in the ages of mothers in rural and urban areas, 33.95 and 36.63 respectively in terms of schooling, the average schooling years of the sampled mother is 5.63 . This shows that an average mother sampled possesses only primary education. As expected the mean schooling years of mothers in the urban centers is higher than that of the rural areas. (6.24 and 5.41 respectively). This implies that low level of education have significant effect on child health. Furthermore, the average per capital expenditure is 20.24. Access to drinking water was used as a proxy for environmental conditions surrounding the child. The statistics shows that households in the rural areas has to go far distance to be able to get drinking water compared to their counterparts in the urban areas. $(2.83 \mathrm{~km}$ and $2.08 \mathrm{~km}$ respectively).

At least 45 percent of the children in the urban centers are fully immunized, while only 33 percent in the rural areas. It is further evident from the result that urban mothers care more about immunisation than rural mothers; this might be as a result of differentials in their educational levels. In general, the percentage of immunised children in both rural and urban areas still shows that immunisation coverage is still low in Nigeria. 
Table 4. Child immunisation status and child morbidity determinants (please note that child morbidity rate is the dependent variables) the figure in parenthesis is the t-statistics

\begin{tabular}{|c|c|c|c|c|}
\hline \multirow{2}{*}{ Variables } & \multicolumn{4}{|c|}{ Estimation Procedures } \\
\hline & OLS & IV & Control Functions & \\
\hline $\begin{array}{l}\text { Childs Immunisation } \\
\text { Status (1= immunised) }\end{array}$ & $0.0103(0.989)$ & $-0.0724(-3.20)$ & $-0.0724(-3.34)$ & $-0.2102(-3.44)$ \\
\hline Mothers age in years & $-0.0014(-14.21)$ & $-0.0014(-11.20)$ & $-0.0014(-10.22)$ & $-0.00136(-10.43)$ \\
\hline Sector (1=Rural) & $0.1082(7.63)$ & $0.0123(1.20)$ & $0.0123(1.24)$ & $0.0234(0.382)$ \\
\hline $\begin{array}{l}\text { Log of per capita exp. On } \\
\text { health. }\end{array}$ & $0.542(3.28)$ & $0.5424(2.22)$ & $0.542(3.44)$ & $0.542(3.42)$ \\
\hline \multicolumn{5}{|l|}{ Control function Variable. } \\
\hline $\begin{array}{l}\text { Reduced from } \\
\text { Immunization residual, V }\end{array}$ & & & $0.2015(4.32)$ & $0.2324(4.42)$ \\
\hline $\begin{array}{l}\text { Immunisation Status by } \\
\text { Immunisation } \\
\text { VXM }\end{array}$ & & & & $0.0044(1.032)$ \\
\hline Constant & $1.034(4.32)$ & $1.220(6.22)$ & $1.010(5.921)$ & $0.985(6.012)$ \\
\hline R-Square & 0.132 & & 0.143 & 0.1520 \\
\hline F-Statistics & & & $78.31(0.001)$ & $73.32(0.000)$ \\
\hline Durbin Watson & & $(0.000)(43.420)$ & & \\
\hline $\begin{array}{l}\text { P-Value of test for over } \\
\text { identification } \\
\text { Instruments }\end{array}$ & & $2.420(0.0123)$ & & \\
\hline Sample Size & 10,965 & 10,965 & 10,965 & \\
\hline
\end{tabular}

All the Variables in this result are significant with the exception of child immunisation in explaining Child morbidity in Nigeria. However, contrast to the findings of Adeoti et al. (2009) other methodologies (IV method and Control Function) Show that the Variables are not significant. The result further reveals an inverse relationship between child Immunisation and child morbidity. Concerning mother's age, the coefficient shows an inverse relationship between morbidity rate and mother's age. The implication of this is that children of younger mothers are likely to have high morbidity compared to older mothers. As expected, there is high morbidity rate in the rural areas compared to urban areas. Per capita expenditure on health further shows that mothers with high income are likely to record less child morbidity compared to their counterparts with low income.

Table 5. Linear probability model the dependent variable $=1$ if immunised and 0 otherwise

\begin{tabular}{|c|c|c|c|}
\hline \multirow[t]{2}{*}{ Variables } & \multirow[t]{2}{*}{ All } & \multicolumn{2}{|l|}{ Residence } \\
\hline & & Rural & Urban \\
\hline Mother's age in years. & $-0.0012(-18.211)$ & $-0.0123(-14.42)$ & $0.6452(3.011)$ \\
\hline Sector (12 Rural) & $-0.0623(-6.41)$ & & \\
\hline Log of per capita exp. On health. & $0.6421(2.91)$ & $0.6531(3.012)$ & $0.6452(3.011)$ \\
\hline Identification variables & & & \\
\hline Mother's Schooling Level & $0.0324(10.41)$ & $0.0311(10.643)$ & $0.0341(8.022)$ \\
\hline $\begin{array}{l}\text { Access to Drinking water (measured by distance to } \\
\text { facility) }\end{array}$ & & $0.0101(0.012)$ & $0.00512(0.442)$ \\
\hline Access housing. $(1=$ modern & $-0.0034(-7.26)$ & & \\
\hline Constant & $0.126(8.410)$ & $0.324(6.241)$ & $0.537(7.45)$ \\
\hline R-Squared & 0.0524 & 0.0532 & 0.0576 \\
\hline F-Stat & $131.51(0.000)$ & $106.23(0.0001)$ & $86.45(0.000)$ \\
\hline Sample Size & 10,965 & 8,325 & 2,640 \\
\hline
\end{tabular}


From table 5 above, the full sample result shows that four variables (mother's age, sector, mother's level of schooling, access to drinking water and access to housing) are significant variables that are likely to influence child morbidity. The same result was obtained for the sub-samples. This result is similar to the one obtained in table 5 concerning mother's age, showing that children of younger mothers are more likely to take immunisation than their older counterpart. Mothers with high level of schooling are more likely to record less child morbidity than their illiterate counterpart. Furthermore, households resident in modern houses are likely to record less child morbidity than their counterparts in old houses. The farther the distance to drinking water, the more likely the rate of child morbidity increases because mothers may not be readily available for child immunisation.

Table 6. Determinants of child morbidity: Control function method (dependent variable child morbidity $=$ rate)

\begin{tabular}{llll}
\hline Variables & Residence & \multicolumn{1}{l}{ Urban } \\
\hline Child Immunisation Status (1 = Immunised) & All & Rural & $-0.1241(-4.254)$ \\
Mother age in years & $-0.0921(-8.23)$ & $-0.0976(-6.104)$ & $-0.00136(-1.261)$ \\
Sector (1 = Rural) & $-0.0124(-11.531)$ & $-0.1011(-9.620)$ & $-0.0063(-0.0062)$ \\
Log of per capital health exp. & $-0.0102(0.411)$ & & \\
Control for variable & $-2.0411(-3.84)$ & $-0.924(-4.36)$ & $0.1123(4.212)$ \\
Reduced from Immunisation $\quad$ Residual, V & & & $-0.0121(-0.672)$ \\
Immunisation stratus by Immunisation residual, Vxm & $0.1035(9.210)$ & $0.1123(6.23)$ & $0.212(4.24)$ \\
Constant & $0.212(9.23)$ & $0.00721(1.321)$ & 0.0214 \\
R-Square & 0.0314 & $0.310(7.23)$ & $42.23(0.000)$ \\
F-Stat & $74.52(0.000)$ & 0.0342 & 2,640 \\
Sample size & 10,965 & $61.21(0.000)$ & 8,325 \\
\hline
\end{tabular}

We obtained similar result with the result presented in Table 5. It is pertinent to state that mother's age is significant in determining the morbidity rate. As the age increases morbidity rate reduces. This result further shows that, older mothers are likely to immunize their children compared to younger ones. In terms of rural and urban sector, the result reveals a high probability of child morbidity in the rural areas.

\section{Policy Implications}

It is evident from our results that child morbidity rate in Nigeria is still very high, this supports WHO's report (2010), that Nigeria has the worst record in Africa in terms of child morbidity and mortality. As a result of this, Nigeria government has to put in place intervention programmes towards child survival, such as: revamping the neglected PHC services: supporting the Roll back Malaria (RBM) and Polio Eradication Initiatives (PEI). The importance of mother's education towards reduction in child morbidity has been revealed by this study. Therefore it is imperative for Nigerian government to fund education adequately especially women education through adequate budgetary provision. The government also needs to do more by increasing funding for routine immunisation of Integrated Management of Childhood Illness (IMCI) programme so as to increase child survival. Lastly, school health programmes needs to be established and also make effective.

\section{References}

Adeoti, A. I., Oni, O. A., Alonge, S. K., \& Akintunde, O. O. (2009). Demand for Reproductive Health, Poverty and Economic Growth in Nigeria. AERC Occasional Paper. Kenya.

Barrera, A. (1990). The Role of Maternal Schooling and its Interaction with Public Health Programmes in child health production. Journal of Development Economics, $32(4)$. http://dx.doi.org/10.1016/0304-3878(90)90052-D

Barrett, H., \& Brown, A. (1996). Health, Hygiene and Maternal Education: Evidence from Gambia. Social Science and Medicine, 43(11). http://dx.doi.org/10.1016/S0277-9536(96)00054-8

Beaton, G. H., Martorell, R., L’Abbe, K. A., Edmanston, B., McCabe, G., Ross, A. C., \& Harvey, B. (1993). Effectiveness of Vitamin A Supplementation in the control of young child morbidity and mortality in developing countries. ACC/SCN State-of-the-Art Nutrition Policy Discussion Paper, No, 13. United Nations.

Bicego, G., \& Boerma, J. (1993). Maternal Education and Chief Survival: A Comparative Study of Survey data from 17 Countries. Social Science and Medicine, 36(8). http://dx.doi.org/10.1016/0277-9536(93)90241-U

Bleichrodt, N., \& Born, M. A. (1994). Meta-Analysis of Research on Iodine and its Relationship to cognitive 
development. In J. B. Stanbury (Ed.), The Damaged Brain of Iodine Deficiency. Cognizant Communication Corporation, New York.

Bloom, A., \& Canning, S. (2003). With the Help of one's Neighbors: Externalities in the Production of Nutrition in Peru. Journal of Social Science and Medicine, 56(10).

Brooks-Gun, \& Duncan, J. (1997). Routes to low mortality in poor countries. Population and Development Review, 12(4).

Cadwell, J. C. (1979). Education as a Factor in Mortality Decline: An Examination of Nigerian Data. Population Studies, 33(3).

Case, A., Lubotsky, D., \& Parson, C. (2005). Economic Status and Health in Childhood: The Origins of the Gradient. The American Economic Review, 92(5).

Case, A., Lubotsky, M., \& Paxson, C. (2002). Economic Status and Health in Childhood: The Origins of the Gradient. American Economic Review, 92(8). http://dx.doi.org/10.1257/000282802762024520

Desai, S., \& Alva, A. (1998). Maternal Education and Child Health: Is there a strong causal Relationship? Demography, 35(1). http://dx.doi.org/10.2307/3004028

Federal Ministry of Women Affairs (FMWA). (2006). Nigeria Gender Statistics Digest. Department of Planning, Research and Statistics. Abuja.

Federal Office of Statistics (FOS)/UNICEF. (2010). Multiple Indicator Cluster Survey. 1999 Draft Data Table, Lagos.

Glewwe, P. (1999). Why Does Mother's Schooling Raise Child Health in Developing Countries? Evidence from Morocco. Journal of Human Resources, 34(1). http://dx.doi.org/10.2307/146305

Grossman, M. (1972). On the Concept of Health Capital and the demand for health. Journal of Political Economy, 80(12). http://dx.doi.org/10.1086/259880

Guo, G. (1998). Strategies Educated Mothers use to ensure the Health of their Children. Journal of Tropical Pediatrics, 36(8).

Gwatkin, D. R. (2003). How well do Health Programmes reach the poor. Lancet, 361(12). http://dx.doi.org/10.1016/S0140-6736(03)12558-5

Haveman, R. H., \& Wolfe, B. S. (1994). Estimating Intergenerational Schooling Effects: A Comparison of Methods.

Hoboraft, J., McDonald, J., \& Rutstein, S. O. (1993). Socio-Economic Factors in Infant and Child Mortality: A Cross-national comparison. Population Studies, 38(9).

Kurz, K. M., Peplinsky, N. L., \& Johnson-Welch, C. (1994). Investing in the Future: Six Principles for Promoting the Nutritional Status of Adolescent Girls in Developing Countries. Washington, DC: International Centre for Research on Women.

National Population Commission. (2006). Nigeria Demographic and Health Survey. Calverion Maryland.

Policy Project/Nigeria. (2002). Reproductive Health in Nigeria; Situation, Response and Prospects: Key Issues. Abuja: Policy Project.

Rubalcavaa, L. N., \& Ternel, G. M. (2004). The Role of Maternal Cognitive Ability on Child Health. Journal of Economics and Human Biology, 12(5). http://dx.doi.org/10.1016/j.ehb.2004.10.009

Smith, J. R. (1998). Health, Nutrition and Economic Development. Journal of Economic Literature, 36(2).

Strauss, J., \& Thomas, D. (1998). Human Resources: Household Decisions and Markets. In J. Behrman, \& T. N. Sriniva-San (Eds.), Handbook of Development Economics (Vol. 3).

United Nations Children's Fund (UNICEF)/Nigeria. (2001). Federal Government of Nigeria and UNICEF Master Plan of Operations for a Country Programme Cooperation for Nigerian Children and Women, 2002-2007. Lagos: UNICEF.

United Nations Development Project (UNDP). (2012). Human Development Report. New York.

Wachs, T. D. (1995). Relation of Mild-to-Moderate Malnutrition to Human Development Correlational Studies. Journal of Nutrition, 125(14).

World Bank. (1999). World Bank Africa Database. Washington D.C: World Bank.

\section{Copyrights}

Copyright for this article is retained by the author(s), with first publication rights granted to the journal.

This is an open-access article distributed under the terms and conditions of the Creative Commons Attribution license (http://creativecommons.org/licenses/by/3.0/). 